\title{
九州歯科大学における大学理念の周知度および大学教育満足度に 関するアンケート調査一学生・卒業生・雇用主・教員での比較
}

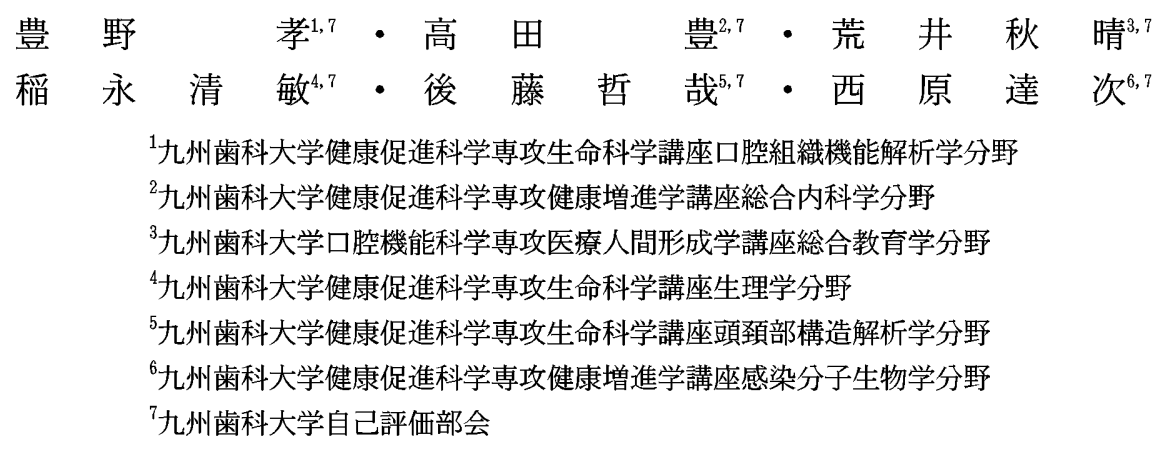

平成 20 年 6 月 16 日受付

平成 20 年 7 月 23 日受理

A Questionnaire Investigating Awareness of the University's of Philosophy and the Satisfaction with Education among Kyushu Dental College Students

Takashi Toyono1, Yutaka Takata ${ }^{2}$, Shusei Arai ${ }^{3}$, Kiyotoshi Inenaga ${ }^{4}$, Tetsuya Goto ${ }^{5}$ and Tatsuji Nishihara ${ }^{6}$

${ }^{1}$ Division of Oral Histology and Neurobiology, Department of Biosciences,

${ }^{2}$ Division of General Internal Medicine, Department of Health Promotion,

Science of Health Improvement,

${ }^{3}$ Division of General Education, Department of Clinical Communication and Practice, Science of Oral Functions,

${ }^{4}$ Division of Physiology, Department of Biosciences,

${ }^{5}$ Division of Anatomy, Department of Biosciences,

${ }^{6}$ Division of Infections and Molecular Biology, Department of Biosciences,

Science of Health Improvement,

Kyushu Dental College, Kitakyushu, Japan

E-mail: toyono@kyu-dent.ac.jp

\begin{abstract}
Investigations of the communication of the university's philosophy and the satisfaction with education among those at Kyushu Dental College have not been conducted. In this study, we used mark-sheet questionnaires with $2^{\text {nd }}$ through $6^{\text {th }}$ year dental students, graduate
\end{abstract}


students, graduated students, employers of graduated students and faculty members of Kyushu Dental College.

The survey concerning awareness of the university's philosophy among the dental students, graduate students, graduated students and faculty members showed that awareness levels among faculty members were higher than those for the others. In contrast, the awareness levels of the university's philosophy for graduated students were lower than those for the others. The awareness levels for $2^{\text {nd }}$ to $5^{\text {th }}$ year students showed that the awareness levels for $2^{\text {nd }}$ year students were higher than those for the others.

Next, the satisfaction with education survey for the dental students, graduate students, graduated students and employers of graduated students showed that the satisfaction levels with education among dental students were higher than those for the others. In contrast, the satisfaction levels with education among graduated students were lower than those for the others. Single regression analysis showed a significant and positive relation between the awareness of university philosophy and the satisfaction with education among the graduate students. A significant but weak positive relation was found between the awareness levels of university philosophy and the satisfaction levels with education among the dental students and graduated students.

It was concluded that the awareness levels of the university's philosophy and the satisfaction levels with education showed differences among various groups. Raising awareness of university philosophy and improving educational content and methods may elevate the satisfaction levels of dental students at Kyushu Dental College.

Key words: Awareness of university philosophy/Education/Satisfaction/Student/Employer

抄 録

大学における教育は大学の基本理念に基づいて行われており, 学生および教員を含めた大学全体での大学理念の周 知が必要である.さらに, 大学での教育成果およびその教育成果が社会のニーズに応えているかを検証するためには, 学内外の多面的な視点から検証を行う必要があると考えられる. そこで, 本研究では歯学部学生 ( $2 \sim 6$ 年生), 大 学院生, 卒業生および教員および本学卒業生の雇用主を対象として大学理念の周知度および大学教育の満足度のマー クシート方式によるアンケート調査を行った.

大学理念の周知度に関しては, 教員の周知度が最も高く, 卒業生が最も低いことが明らかになった，歯学部学生の 各学年での周知度では， 2 年生が最香周知度が高かった. 次に大学教育の満足度に関しては, 歯学部学生の満足度が 最泉高く, 卒業生が最も低いことが明らかになった，大学理念の周知度および大学教育の満足度の関係を単回帰分析 で調べたところ, 歯学部学生および卒業生は弱い正の関係が, 大学院生は高い正の関係が認められた.

これらの結果より, 大学理念の周知度抢よび大学教育の満足度において対象群において差が認められた。 今後は歯 学部学生に㧍ける本学理念の周知の徽底を図ると同時に, 大学教育の満足度が向上するょうに本学での教育内容拉よ び方法の改善に取り組む必要があると考えられた。

キーワード : 大学理念/教育/満足度/学生/雇用主 


\section{緒 言}

大学に打ける教育は大学の基本理念に基づいて行われ ている. その基本理念は, 各大学の建学理念㧍よび役割 に基づいて制定されている ${ }^{1,2}$. 九州歯科大学の基本理念 は，「高度な専門性を持った歯科医師の育成」「地域医療 の中核的役割を果たす」「歯科医学を支える研究の推進」 を謳っており，これらの基本理念に基づいて本学での教 育が行われている。しかしながら, 本学学生がこれらの 理念をきちんと意識しながら教育を受けているかは、こ れまで基本理念の周知度に関する調查が行われてないこ とから不明であった。そこで, 本研究では歯学部学生, 大学院生, 卒業生および教員を対象として基本理念の周 知度をアンケート調查により調べた。

大学の基本理念に基づいた教育の成果を向上させるた めには, 教育実態の把握と教育成果の検証が不可欠であ る. 本学ではその為に, 各教科に対する達成度および満 足度調查, 学習環境の満足度調查および, 大学院生の教 育・研究に関する意識および実態調查などを行ってき だ-6).このように,これまでは主に学内の学生を対象と して検証を行ってきたが, 本学での教育成果およびその 教育成果が社会のニーズに応えているかを検証するため には，学内外の多面的な視点から検証を行う必要がある と考えられた，そこで，本研究では本学での教育成果の 検証の一環として, 歯学部学生, 大学院生, 卒業生扔よ
び教員のみならず本学卒業生の雇用主を対象として教育 満足度の検証を行った。

\section{対象および方法}

本調査は九州歯科大学歯学部学生および大学院生の以 下の全学生 (歯学部学生 2 年生 (97 名), 3 年生 (95 名), 4 年生 $(91$ 名), 5 年生 (96 名), 6 年生 (110 名), 大 学院生 2 年生 (6 名), 3 年生 (20 名), 4 年生 (19名)) および全教員（120名）を対象とした。卒業生に関して は，職場環境への順応期間などを考慮し，順応途中と考 えられる卒業後 1 年目と, 順応していると考えられる卒 業 5 年目を対象とした。 1 年目扔よび 5 年目卒業生の中 から, 今回のアンケートを行うにあたって連絡先が明ら かになった 170 名全員を対象とした。卒業生の雇用主に 関しては, 卒業生の全雇用者の中から連絡先が明らかに なった 51 名全員を対象とした，本調查はマークシート 形式による，無記名によるアンケート調査により 4 月に 行った. 本学理念の周知度に対する回答を 5 から 1 の 5 段階評価 (5大変よく知っている，4 功り知っている, 3 まあまあ知っている，2 あまり知らない，1全く知ら ない）で設定し（表 1)，5段階評価のそれぞれの割合

（\%)を算出した。ささらに周知度 5 と 4 を高周知度群, 1 と 2 を低周知度群として, 各対象の比較を行った. 次 に各対象の, 周知度の得点数 (平均土標準偏差) を算出 した。 各対象の周知度の有意差検定には, Kruskal-

表 1 大学理念㧍よび教育満足度についてのアンケート項目

\begin{tabular}{|c|c|c|c|c|c|c|}
\hline 設問番号 & アンケート内容 & \multicolumn{5}{|c|}{ 選択 } \\
\hline & & $\begin{array}{l}\text { 大変よく } \\
\text { 知っている }\end{array}$ & $\begin{array}{c}\text { かなり } \\
\text { 知っている }\end{array}$ & $\begin{array}{l}\text { まあまあ } \\
\text { 知っている }\end{array}$ & $\begin{array}{c}\text { あまり } \\
\text { 知らない }\end{array}$ & $\begin{array}{c}\text { 全く } \\
\text { 知らない }\end{array}$ \\
\hline 1 & $\begin{array}{l}\text { 本学の理念として「高度な専門性を } \\
\text { 持った歯科医師の育成」をうたって } \\
\text { います。この理念を知っていますか。 }\end{array}$ & 5 & 4 & 3 & 2 & 1 \\
\hline 2 & $\begin{array}{l}\text { 本学の理念として「地域医療の中核 } \\
\text { 的役割を果たす」をうたっていま } \\
\text { す。この理念を知っていますか。 }\end{array}$ & 5 & 4 & 3 & 2 & 1 \\
\hline \multirow[t]{2}{*}{3} & $\begin{array}{l}\text { 本学の理念として「歯科医学を支え } \\
\text { る研究の推進」をうたっています。 } \\
\text { この理念を知っていますか。 }\end{array}$ & 5 & 4 & 3 & 2 & 1 \\
\hline & & 高い & & $\rightarrow$ & & 低い \\
\hline 4 & $\begin{array}{l}\text { あなたが本学で受けた教育の満足度 } \\
\text { を } 5 \text { 段階で評価してください。 }\end{array}$ & 5 & 4 & 3 & 2 & 1 \\
\hline
\end{tabular}


Wallis 検定を用いた. 教員について年齢および勤務年数 そ, 理念の周知度の関係を調べた.

本学での教育の満足度に対する回答を 5 から 1 の 5 段 階評価（ 5 が最高で， 1 が最低）で設定し（表 1 ）， 5 段階評価のそれぞれの割合（\%）を算出した。ささらに満 足度 5 と 4 を満足群, 1 と2 不満足群として, 各対象 の比較を行った. 次に各対象の, 教育満足度の得点数 (平均土標準偏差) を算出した. 各対象の教育満足度の 有意差検定には, Kruskal-Wallis 検定を用いた。

さらに大学理念の周知度および満足度間の関係につい て単回帰分析で Spearman 順位相関係数 (r) を算出し た.これらの統計分析は JMP Version 6.0 (SAS Institute Japan）で行った.

\section{結果}

\section{I 、対象者}

歯学部学生の全対象者 489 名中 412 名からアンケート を回収した、アンケート回収率は $84.3 \%$ あっった，大学 院生の全対象者 45 名中 34 名からアンケートを回収し た.アンケート回収率は $76 \%$ であった. 卒業生の全対象 者 170 名中 101 名からアンケートを回収した.アンケー ト回収率は $59 \%$ であった. 教員の全対象 120 名中 98 名 からアンケートを回収した。 アンケート回収率は $82 \%$ であった．卒業生の雇用主の全対象 51 名中 27 名からア ンケートを回収した。 アンケート回収率は $53 \%$ であっ
た. 全体での回収率は $76.8 \%$ \%゙あた。

II. 大学理念の周知度 5 段階評価の割合之高周知度群之 低周知度群割合の比較

各対象群の大学理念の周知度を図 1 に示す。高周知度 群の割合が高い対象群の順番は教員 $(58 \%)$, 大学院 (24\%), 歯学部学生 $(16 \%)$, 卒業生 (11\%) の順で あった。一方, 低周知度群の割合が低い対象群の順番は 教員 $(7 \%)$, 大学院 $(34 \%)$, 歯学部学生 $(41 \%)$, 卒 業生 $(49 \%)$ の順であった.このように, 教員において は各対象群の中で最す高周知度群の割合が高值であり, 低周知度群の割合が低値であった。

歯学部学生に関して, 学年間での周知度の関係を調べ た (図 2). 高周知度群の割合が高い学年の順番は 2 年生 (24\%), 4 年生 (20\%), 6 年生 (13\%), 3 年生 (11\%), 5 年生 $(10 \%)$ の順であった。一方, 低周知度群の割合 が低い学年の順番は 2 年生 $(30 \%), 4$ 年生 (42\%), 3 年生, 5 年生, 6 年生 (それぞれ $44 \%$ ) の順であった. 次に教員に関して，その年齢拉よび勤務年数之理念の 周知度の関係を調べた（図 3 ）。教員年齢 39 才以下では

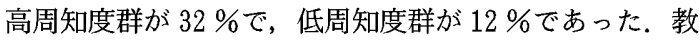
員年齢 $40 \sim 49$ 才では高周知度群が $72 \%$ ，低周知度 群が $3 \%$ あった. 教員年齢 50 才以上では高周知度群 が $71 \%$ ，低周知度群が $6 \%$ あった。このように教員 においては，教員年齢が 39 才以下では 40 才以上と比較 して, 高周知度群が少なく, 低周知度群が多い傾向がみ

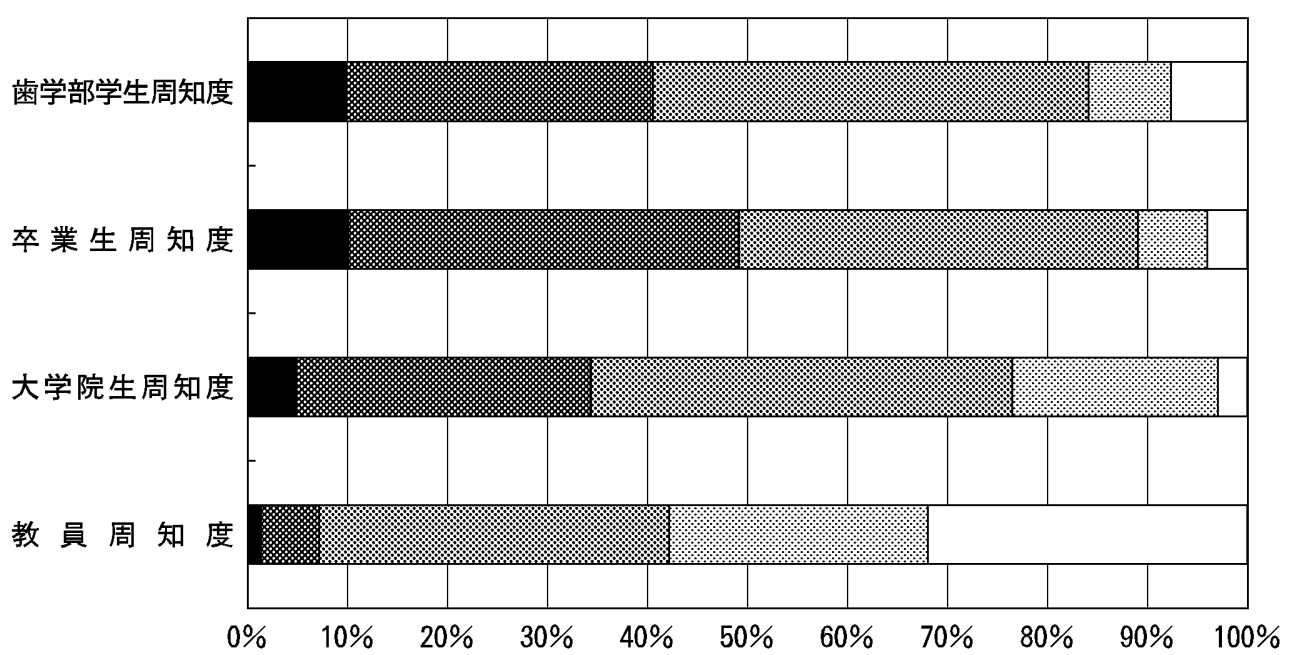

全く知らない 网あまり知らない 图まあまあ知っている 圈かなり知っている 口大変よく知っている

図 1 大学理念の周知度. 


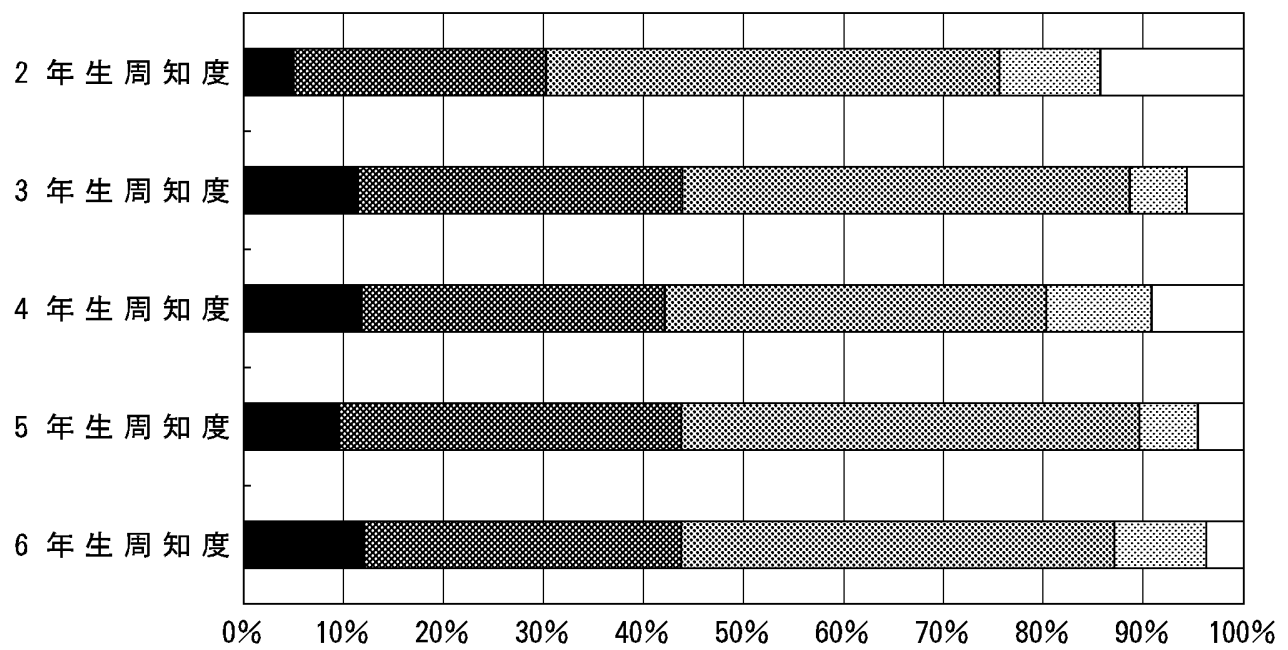

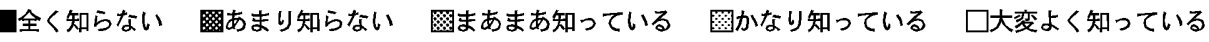

図 2 歯学部学生の大学理念の周知度.

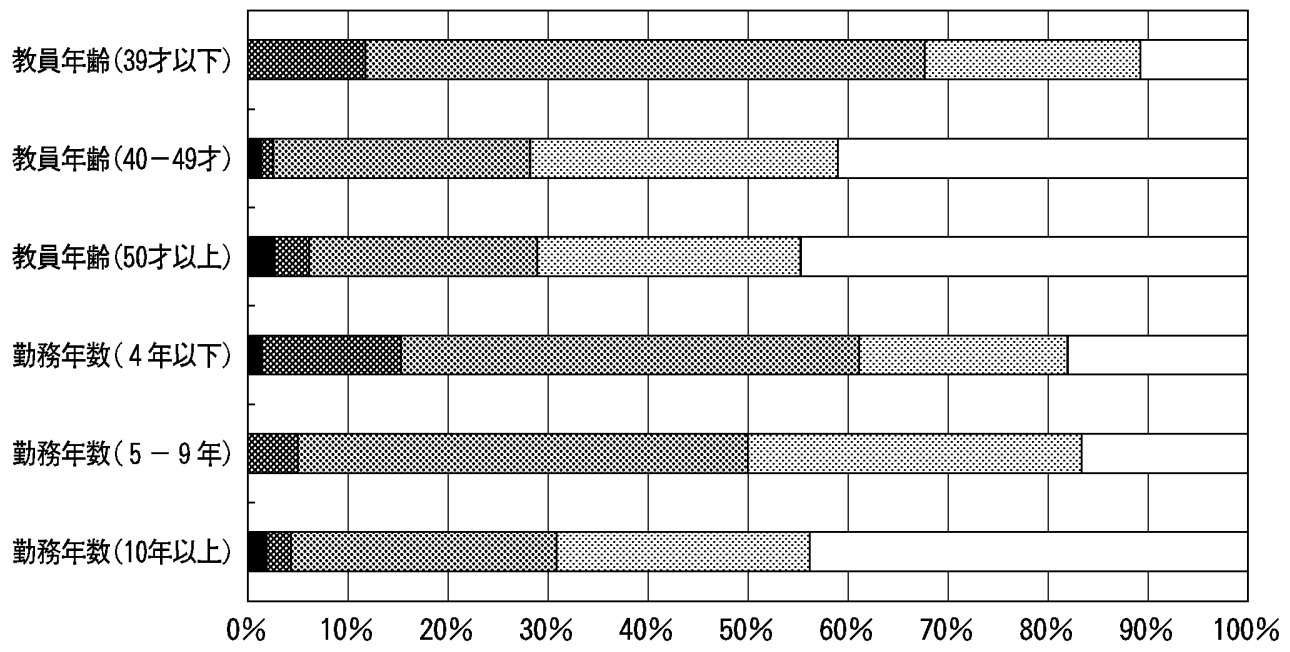

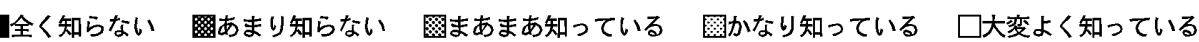

図 3 教員の理念周知度.

られた. 一方勤務年数では勤務年数 4 年以下では高周知 度群が $39 \%$ で, 低周知度群が $15 \%$ あったた. 勤務年数 $5 \sim 9$ 年では高周知度群が $50 \%$ で, 低周知度群が $5 \%$ であった. 勤務年数 10 年以上では高周知度群が $69 \%$ で，低周知度群が $4 \%$ であった。このように勤務年数の
増加につれ, 高周知度群が増加し, 低周知度群が減少す る傾向がみられた。

III. 大学理念の周知度の対象群間差

大学理念の周知度について, 対象群間で異なるかどう かを調べた (表 2). その結果, 大学理念の周知度に沶い 
て有意の対象群間の差を認めた. 大学理念の周知度につ いては歯学部学生, 卒業生, 大学院生 $(2.56 \sim 2.87)$ と あまり差は認められなかったが, 教員においては 3.81 と 高值であった，次に，歯学部学生に関して，周知度が学 年間で異なるかどうかを調べた（表 3 ），その結果，大学 理念の周知度において有意の学年間の差を認めた. 大学 理念の周知度については 3 年生, 4 年生, 5 年生, 6 年 生（2.61〜2.75）においてあまり差は認められなかった が， 2 年生においては 3.03 と高值であった。
IV. 満足度 5 段階評価の割合と満足者と不満足者割合の 比較

各対象群の大学教育への満足度を調べた（図 4 ). 満足 群（満足度 4 と 5) の割合が高い順番は歯学部学生 (43\%), 大学院生, 雇用主（それぞれ $38 \%$ ), 卒業生 （18\%）の順であった. 一方, 不満足群 (満足度 1 と 2) の割合が低い対象群の順番は歯学部学生 $(10 \%)$, 卒業 生 $(17 \%)$, 大学院生 $(18 \%)$, 雇用主 $(31 \%)$ の順で あった

歯学部学生に関して，学年間での満足度の関係を調心゙

表 2 大学理念の周知度点数

\begin{tabular}{c|c|c|c|c|c}
\hline \hline 内容 & 歯学部学生 & 卒業生 & 大学院生 & 教員 & $\begin{array}{c}\text { Kruskal Wallis } \\
\text { 検定 (P 值) }\end{array}$ \\
\hline 周知度 & $2.73 \pm 1.01$ & $2.56 \pm 0.91$ & $2.87 \pm 0.90$ & $3.81 \pm 1.00$ & 0.000 \\
\hline
\end{tabular}

表 3 歯学部学生の大学理念の周知度点数

\begin{tabular}{c|c|c|c|c|c|c}
\hline \hline 内容 & 2 学年 & 3 学年 & 4 学年 & 5 学年 & 6 学年 & $\begin{array}{c}\text { Kruskal Wallis } \\
\text { 検定 (P 值) }\end{array}$ \\
\hline 周知度 & $3.03 \pm 1.06$ & $2.62 \pm 0.96$ & $2.75 \pm 1.09$ & $2.62 \pm 0.91$ & $2.61 \pm 0.94$ & 0.000 \\
\hline
\end{tabular}

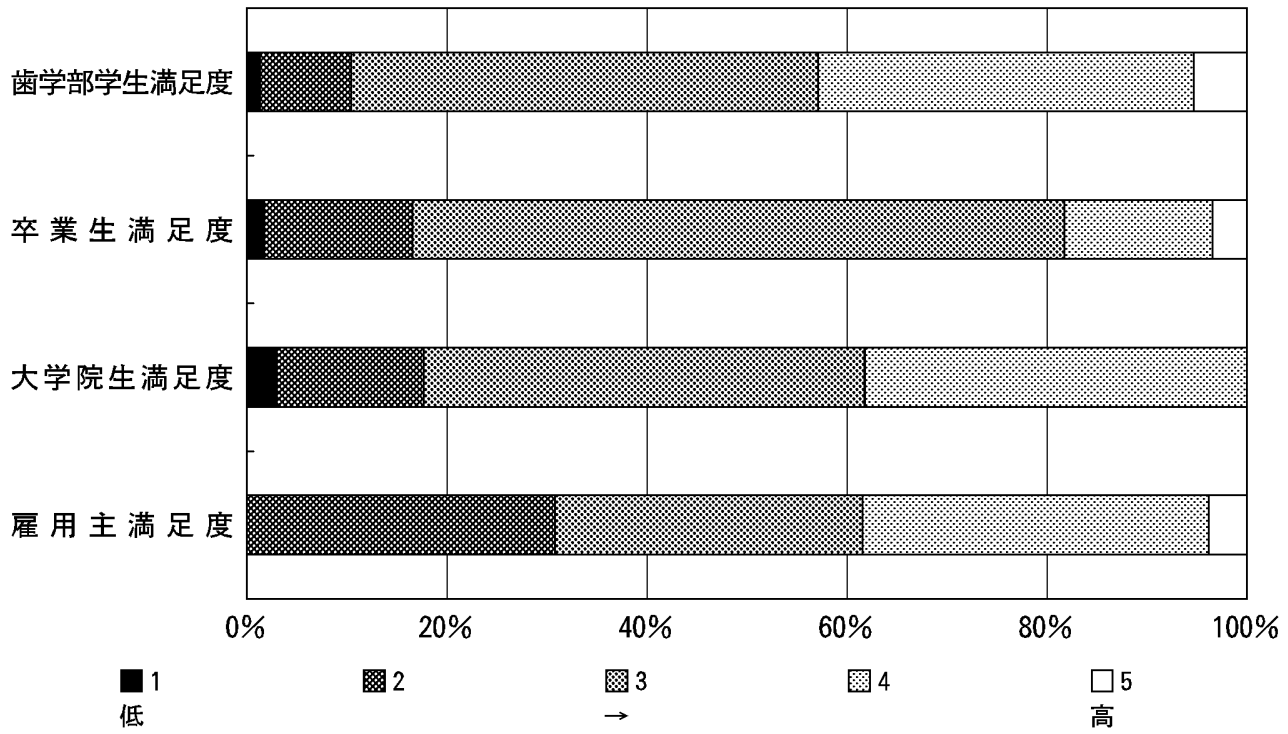

図 4 大学教育への満足度. 


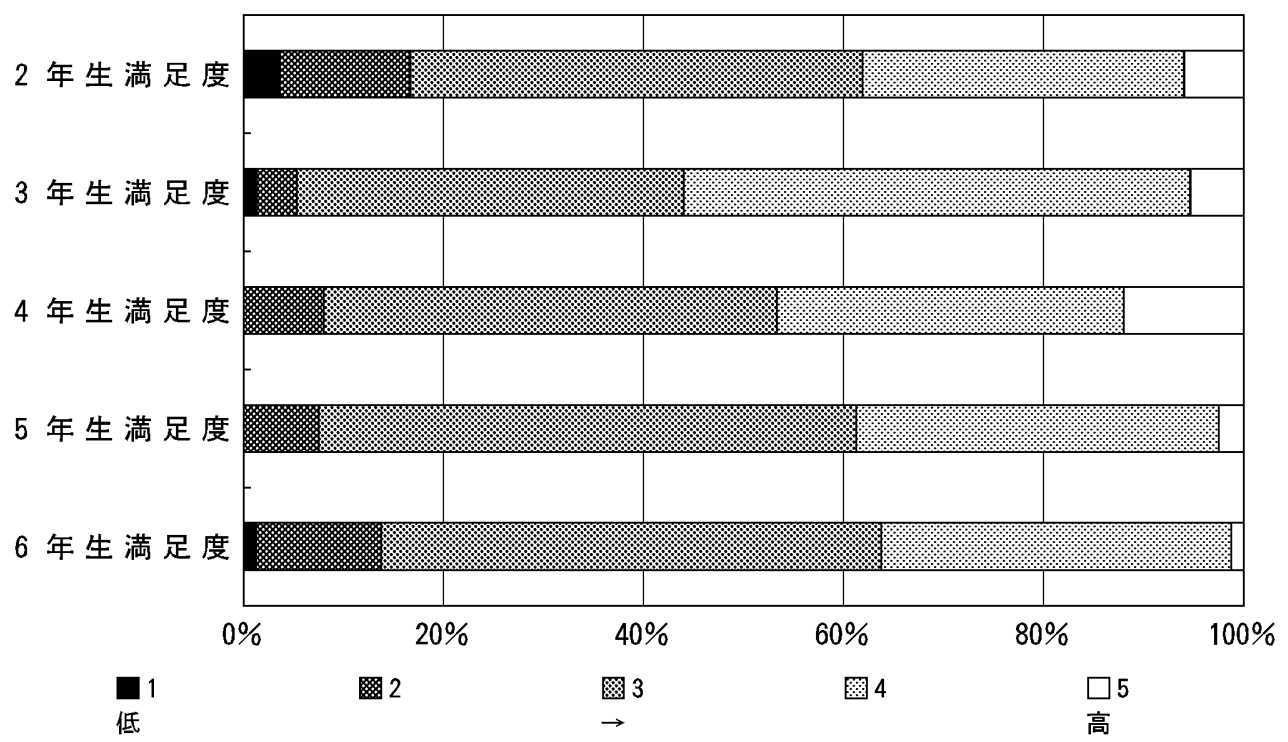

図 5 歯学部学生の大学教育への満足度.

た（図 5 ). 満足群の割合が高い学年の順番は 3 年生 $(56 \%), 4$ 年生 $(47 \%), 5$ 年生 $(39 \%), 2$ 年生 $(38 \%)$, 6 年生 (36\%) の順であった. 一方, 不満足群の割合が 低い学年の順番は 3 年生 ( $5 \%$ ), 4 年生, 5 年生（そ れぞれ $8 \%) ， 6$ 年生 (14\%)，2 年生 (17\%) の順で あった。

\section{V. 満足度の対象群間差}

大学教育への満足度について, 各対象群で異なるかど うかを調べた（表 4)。その結果，大学教育への満足度に ついては歯学部学生が 3.37 で最も高値で, 卒業生が 3.03 と最あ低值であった. 次に歯学部学生に関して, 大学教
育への満足度が学年間で異なるかどうかを調べた（表 5 ). その結果, 満足度については 2 年生, 5 年生, 6 年生（3.23〜 3.34）とあまり差は認められなかったが, 3 年生および 4 年生においてはそれぞれ 3.55 および 3.51 と高値であった。

VI. 大学理念の周知度および大学教育への満足度の関係 大学理念の周知度および大学教育の満足度の関係を単 回帰分析で調べた．単回帰分析では Spearman 順位相 関係数 ( $\mathrm{r}$ ) と有意確率 (両側) $\mathrm{p}$ 値を算出した（表 6). $\mathrm{p}$ 值は全て 0.000 で, 単回帰分析では大学理念の周知度 および大学教育の満足度の間に有意の正の関係が認めら

表 4 大学教育の満足度点数

\begin{tabular}{c|c|c|c|c|c}
\hline \hline 内容 & 歯学部学生 & 卒業生 & 大学院生 & 雇用主 & $\begin{array}{c}\text { Kruskal Wallis } \\
\text { 検定 (P值) }\end{array}$ \\
\hline 満足度 & $3.37 \pm 0.77$ & $3.03 \pm 0.71$ & $3.18 \pm 0.80$ & $3.12 \pm 0.91$ & 0.0001 \\
\hline
\end{tabular}

表 5 歯学部学生の大学教育の満足度点数

\begin{tabular}{c|c|c|c|c|c|c}
\hline \hline 内容 & 2 学年 & 3 学年 & 4 学年 & 5 学年 & 6 学年 & $\begin{array}{c}\text { Kruskal Wallis } \\
\text { 検定 (P 值) }\end{array}$ \\
\hline 満足度 & $3.24 \pm 0.89$ & $3.55 \pm 0.72$ & $3.51 \pm 0.81$ & $3.34 \pm 0.65$ & $3.23 \pm 0.73$ & 0.0271 \\
\hline
\end{tabular}


表 6 大学理念の周知度および大学教育の満足度の関係 の単回帰分析

\begin{tabular}{c|c|c}
\hline \hline 対象群 & 相関係数 $(\mathrm{r})$ & $\mathrm{P}$ 值 \\
\hline 歯学部学生 & 0.260 & 0.000 \\
\hline 卒 業 生 & 0.286 & 0.000 \\
\hline 大 学 院 生 & 0.522 & 0.000 \\
\hline
\end{tabular}

れた，相関係数值からみると，歯学部学生および卒業生 に打いては周知度と満足度は弱い正の関係で, 大学院生 においては周知度と満足度は高い正の関係であった。

\section{考察}

今回のアンケート調查から本学における大学理念の周 知度に関して,これらの得点数の平均值の比較を行っ た。 その結果, 教員の周知度が最む高く, 卒業生の周知 度が最す低いことが明らかになった，歯学部学生におい ては 2 年生が他の学年と比較して, 周知度の平均点が最 も高かった. 歯学部学生は志望大学を選ぶ際に, 本学の 大学理念を周知していると考えられる.したがって， 2 年生は入学してからの, 在学年数, すなわち入学後の経 過年数が他の学年と比較して短いためにこのように周知 度が高いことが推測された，卒業生において周知度が最 す低い原因としては, 在学期間中の大学理念の周知不足 が推察された.

教員と比較して, 歯学部学生および大学院生は約 1 ポ イントの周知度点数の開きがあることが明らかになっ た. 大学教育の前提として，教員および学生を含めた大 学全体での基本理念の周知の徹底が必要だと考えられ る. そこで今後は歯学部学生および大学院生の大学理念 の周知度の向上に努めなければならないと考えられた。 歯学部学生および大学院生の大学理念の周知度が向上す れば，卒業生における理念の周知度が向上することも期 待される.

大学教育の満足度については歯学部学生が最す高く, 卒業生が最す低かった。これは実際の臨床の現場で働い ている卒業生にとって, 大学で受けた教育が, 臨床の現 場では満足出来ていないことを示していると考えられ る. そこで今後は卒業生の大学教育の不満点を調べ, そ の点に関して大学教育の改善を図っていく必要があると 考えられる。卒業生の教育満足度が最も低值であること 加ら, 卒業生の雇用主も大学教育の満足度が低いことが 予想された。しかしながら, 実際は大学院生之同程度の
満足度で，卒業生ほど低值ではなかった。このことは， 各雇用主にとって, 卒業生に対する期待にバラッキがあ ると考えられるが, 本学卒業生が受けた教育は, ある程 度満足出来る傾向任あると考元られる。一方, 雇用主に おいては他の対象群と比較し不満足群の割合が最も高 かった. したがって, 今後は雇用主の大学教育への不満 点を調べ，その点に関して大学教育の改善を図り，雇用 主の大学教育に対する満足度を上昇させる必要があると 考えられる. 大学が社会へ貢献するためには, 実際の社 会からのニーズを知り，それに応えることが重要である と考えられる. 社会加らのニー゙には, 患者からのニー ズや, 雇用主からのニーズなど様々なニーズがある.こ れらのニーズの一つとして, 雇用主から期待される歯科 医師を育成することがあると考えられる，本学がこの ニーズに応えることで社会に貢献することは, 同時に本 学卒業生の就職支援にもつながると考えられる。

歯学部学生の教育満足度は, 各学年の中で 3 年生の満 足群の割合が最も高く, 4 年生から 6 年生になるにした がって, その割合が減少していることが認められた。本 アンケートは 4 月に実施しているので, 歯学部学生の教 育満足度は 1 学年前の学年までに受けた教育の満足度を 示している. 2 年生の講義㧍よび実習は 1 年生と比べ教 養科目の割合が減少し，歯科と関連した基礎科目の割合 が増加する, さらに 3 年生以降は講義および実習におけ る臨床科目の割合が増加する ${ }^{5}$. したがって 3 年生にお いて教育満足度が他の学年に比べ高いのは, 歯科之関連 した基礎科目などを 2 年生から受講し歯科に対しての興 味が高まるためだと推測される。 4 年生から 6 年生にな るにしたがって, 臨床之関連した講義および実習の割合 が増加することから, 満足度が上昇することが予想され た. しかしながら, 満足群の割合の減少が認められたこ とから，今後はごのような理由により満足度が減少して いるかを検証していく必要があると考えられる。

大学教育の満足度に関わるファクターとしては, 大学 での講義および実習の他にも，それに関わる教員や，大 学施設などが挙げられる。これまでに我々は大学教育の 満足度拉よび大学施設の満足度が関係していることを報 告している6). 今後は本学に扔いてどのファクターが大 学教育の満足度に強く関わっているかを調べていく必要 があると考えられる.さらに上記ファクター以外のファ クターも大学教育の満足度に関わっている可能性も考え られるので, その点に関しても検索していく必要がある と考えられる.

本研究により歯学部学生の満足度は高く, 卒業生の満 
足度が低い事が明らかになり, 学内の歯学部学生の評価 之, 学外の卒業生の評価が異なる結果が得られた。 大学 教育の成果を評価するには，学内での調查に加えて卒業 生および雇用主などの学外からの評価す必要かつ重要で ある事が本研究により示されたと考えられる.

これらの結果より, 本学理念の周知度に歯学部学生お よび教員において差が認められたことから, 今後は本学 での教育を行う上での前提として歯学部学生における本 学理念の周知の徹底を図る必要がある.さらに卒業生お よび卒業生の雇用主における本学教育の不満足な点を検 証するとともに，その点の改善に取り組む必要があると 考えられた。

\section{結論}

大学理念の周知度に関して, 歯学部学生, 大学院生, 卒業生および教員間で比較したところ, 教員の周知度が 最む高く，卒業生が最も低いことが明らかになった，歯 学部学生の各学年での周知度は, 2 年生の周知度が最む 高かった. 次に大学教育の満足度に関して, 歯学部学生, 大学院生, 卒業生の雇用主および卒業生間で比較を行っ た．その結果, 歯学部学生の満足度が最も高く, 卒業生 が最む低いことが明らかになった．大学理念の周知度お よび大学教育の満足度の関係を単回帰分析で調べたとこ ろ, 歯学部学生および卒業生においては弱い正の関係 が, 大学院生においては高い正の関係が認められた。

これらの結果より, 本学理念の周知度に歯学部学生㧍 よび教員において差が認められたことから, 今後は歯学 部学生における本学理念の周知の徹底を図る必要があ る. 大学教育の満足度に関して，卒業生が最も低功た ことから今後は，卒業生および卒業生の雇用主における
本学教育の不満足な点を検証するととあに, その点の改 善に取り組む必要があると考えられた。

\section{謝辞}

本研究を行うにあたり御助言をいただきました九州歯 科大学総合教育学の平川要教授, 中原孝洋先生に深く感 謝申し上げます．さらにこの研究の実施運営に多大な御 支援をいただきました本学学務部長の神園勝義様, 教務 企画班長の麻川和久様, 教務企画班の堀川小百合様, 松 尾秀治様, 明石伸治様, 総務班の佐野啓二様, 学生支援 班の宮崎隆博様, 安藤佳子様の皆様に深く感謝申し上げ ます。

\section{引用文献}

1）大西健夫, 佐藤能丸: 私立大学の源流「志」と「資」の大 学理念. 学文社, 東京, 2006, 1-16.

2）赤岡 巧: 京都大学の基本理念について. 京大広報 564: 1181-1184, 2002.

3）後藤哲哉, 小林 繁, 本田栄子, 船越啓右, 天野仁一朗, 河岸重則, 吉野賢一, 村田貴俊, 井上博雅, 辻澤利行他: 学 生の基礎歯科学志向に対する基礎配属（研究室配属）の効 果について. 日歯教誌 20: 396-404, 2005.

4) 稲永清敏, 高田 豊, 豊野 孝, 荒井秋晴, 後藤哲哉, 西 原達次: 九州歯科大学大学院生の教育・研究に関する意識 および実態調查. 九州歯会誌 62:48-56, 2008.

5 ）豊野孝, 高田 豊, 荒井秋晴, 稲永清敏, 後藤哲哉, 西 原達次: 九州歯科大学歯学部学生の講義および実習の達成 度および満足度に関するアンケート調查. 日歯教誌 23 ： $341-349,2007$.

6) 高田 豊, 豊野 孝, 荒井秋晴, 稲永清敏, 後藤哲哉, 西 原達次: 九州歯科大学歯学部学生の学習環境満足度調查結 果について. 日歯教誌 $24: 25-32,2008$. 